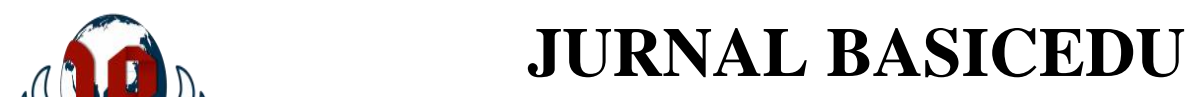

Volume 5 Nomor 5 Tahun 2021 Halaman 3043 - 3049

Research \& Learning in Elementary Education https://jbasic.org/index.php/basicedu

\title{
Implementation of the STAD Type Cooperative Learning Model to Improve Students' Motivation and Civics Learning Outcomes
}

\author{
Sepriandison Saragih \\ University of HKBP Nommensen Pematangsiantar, Indonesia \\ E-mail: sepriandisaragih@gmail.com
}

\begin{abstract}
Abstrak
Penelitian ini bertujuan untuk meningkatkan motivasi dan hasil belajar PKn pada siswa kelas X-4 SMA Negeri 3 Pematangsiantar dengan menerapkan model pembelajaran kooperatif tipe STAD. Penelitian ini merupakan penelitian tindakan kelas yang dilakukan di SMA Negeri 3 Pematangsiantar, subjek penelitian ini adalah siswa kelas X-4 yang berjumlah 30 siswa. Hasil penelitian menunjukkan bahwa hasil belajar siswa pada nilai dasar nilai rata-rata 48,61 meningkat sebesar 16,95 poin menjadi 65,56 pada siklus I. Pada siklus II skor rata-rata meningkat 71,67 dari siklus I sebesar 6,11 poin. Ketuntasan klasikal pada nilai dasar 33\% (13 siswa). Pada tes siklus I ketuntasan meningkat menjadi 72,5\% (19 siswa). Pada siklus II ketuntasan klasikal meningkat menjadi 87,5\% (25 siswa). Dari hasil penelitian dapat disimpulkan bahwa penerapan model pembelajaran kooperatif tipe Student Teams Achievement Division (STAD) dapat meningkatkan motivasi dan hasil belajar PKn pada siswa kelas X-4 SMA Negeri 3 Pematangsiantar.
\end{abstract}

Kata Kunci: Model Pembelajaran Kooperatif Tipe Stad, Motivasi, Hasil Belajar, PKn

Abstract

This study aims to increase the motivation and learning outcomes of Civics in class X-4 SMA Negeri 3 Pematangsiantar by applying the STAD type cooperative learning model. This research is a classroom action research conducted at SMA Negeri 3 Pematangsiantar, the subjects of this research are students of class $X-4$ with a total of 30 students. The results showed that student learning outcomes at the basic score of the average value of 48.61 increased by 16.95 points to 65.56 in the first cycle. In the second cycle the average score was 71.67 increase from the first cycle of 6.11 points. Classical completeness on a base score of $33 \%$ (13 students). In the first cycle test, the completeness increased to $72.5 \%$ (19 students). In the second cycle, classical completeness increased to $87.5 \%$ (25 students). From the results of the study, it can be concluded that the application of the cooperative learning model of the student teams achievement division (STAD) type can increase the motivation and learning outcomes of Civics in class X-4 SMA Negeri 3 Pematangsiantar.

Keywords: Stad Type Cooperative Learning Model, Motivation, Learning Outcomes, Civics

Copyright (c) 2021 Sepriandison Saragih

Corresponding author :

Email : sepriandisaragih@gmail.com

DOI : $:$ https://doi.org/10.31004/basicedu.v5i5.1238

ISSN 2580-3735 (Media Cetak)

ISSN 2580-1147 (Media Online) 
3043 Implementation of the STAD Type Cooperative Learning Model to Improve Students' Motivation and Civics Learning Outcomes - Sepriandison Saragih

DOI: https://doi.org/10.31004/basicedu.v5i5.1238

\section{INTODUCTION}

Education is one of the most important components in the history of human civilization. In addition, education is an integral activity that includes targets, methods, and means informing human beings who can interact and adapt to their environment, both internally and externally for the realization of better progress (Siahaan, Lumbangaol, et al., 2021).

Following (Nanggala, 2020) the tates that civic education is intended to shape students into good citizens, to make a nation with a Pancasilaist character, so Civics (Citizenship Education) is one of the subjects that must be taught in high schools. In carrying out its socio-academic mission, Civics plays a role in developing students' competencies in terms of academic skills, especially in developing critical thinking, analytical, reflective, self-discovering, and problem-solving skills as well as being responsible for developing awareness of living in society, nation and state (Silvia et al., 2012). In carrying out its socio-cultural mission, Civics is obliged to provide facilities for students to practice the knowledge, values, and skills they already possess to be able to contribute to various forms of social participation following the level of development and abilities of students. Students in this case can actively participate in several forms of community service (Pratama et al., 2019). Civic education is one of the subjects that can form a diverse self in terms of religion, socio, culture, language, age, to become intelligent, skilled, and character citizens based on the 1945 Constitution (Nasozaro, 2019).

This is following what was stated by Pangalila,( 2017) that citizenship education is a subject that generally aims to develop the potential of individual Indonesian citizens so that they have adequate insight, attitudes, and citizenship skills and allow them to participate intelligently and effectively. Responsible in various life of society, nation, and state. It is clear to us that Civics aims to develop the potential of individual citizens. To achieve the vision, mission, and goals of Civics, a teacher should be able to design learning in the classroom creatively and innovatively (Zuriah, 2020). But in reality, so far Civics learning only uses the lecture method and tends to be oriented to very theoretical concepts, besides that teachers tend to be monotonous without paying attention to the right media and learning models used to be able to increase the activity and learning outcomes of Civics so that students assume that Civics learning is very boring (Muchtarom, 2017).

Based on initial observations in the field that there are problems related to student learning outcomes, especially students of class X4 State Senior High School 3 Pematangsiantar, namely the KKM (Minimum Completeness Criteria) for Civics lessons in class $\mathrm{X}$ is 75 but the average student scores obtained are 72 with 54\% completeness. Observing the low grades achieved by students are below the specified minimum completeness standard, namely, the Minimum Completeness criteria (KKM), shows that some students are still below the standard. That of the 24 students, there are still many students who get scores below 75 . In this regard, it requires teachers to restore the learning situation in the hope of being able to meet the specified KKM. The problem above can be one of the reasons why Civics learning in schools has not met expectations in the results obtained. In response to the above problems, appropriate learning methods or models are needed to improve student learning outcomes in Civics learning (Simanjuntak et al., 2020).

Based on the background of the problem above, the formulation of the research problem is whether the application of the cooperative learning model type students teams achievement division (STAD) can increase the motivation and learning outcomes of Civics Class X-4 SMA Negeri 3 Pematangsiantar? The purpose of this study was to improve Civics learning outcomes for X-4 graders of SMA Negeri 3 Pematangsiantar by applying the student team achievement division (STAD) cooperative learning model. The cooperative learning model is a learning activity using groups helping each other construct concepts, solve problems or inquiries. According to theory and experience, so that groups are cohesive (compact-participatory), each group member 
3044 Implementation of the STAD Type Cooperative Learning Model to Improve Students' Motivation and Civics Learning Outcomes - Sepriandison Saragih

DOI: https://doi.org/10.31004/basicedu.v5i5.1238

consists of 4-5 people, students are heterogeneous (ability, gender, character), there is control and facilitation, and ask for responsibility for group results in the form or presentation (Priansa, 2017)

Octavia, (2020) suggested that in the steps of cooperative learning there are 6 phases. The learning steps can be seen from the following table.

Table 1. STAD Type Cooperative Learning Steps Pembelajaran

\begin{tabular}{cl}
\hline Phase & \multicolumn{1}{c}{ Teacher Activities } \\
\hline $\begin{array}{c}\text { Phase 1 Delivering goals and } \\
\text { motivating students }\end{array}$ & $\begin{array}{l}\text { The teacher conveys the learning objectives to be achieved in the } \\
\text { lesson and emphasizes the importance of the topic to be studied and } \\
\text { motivates students to learn. }\end{array}$ \\
\hline $\begin{array}{c}\text { Phase 2 Presenting } \\
\text { information }\end{array}$ & $\begin{array}{l}\text { The teacher presents information or material to students by way of } \\
\text { demonstrations or through reading materials. }\end{array}$ \\
\hline $\begin{array}{c}\text { Phase 3 Organizing students } \\
\text { into study groups }\end{array}$ & $\begin{array}{l}\text { The teacher explains to students how to form study groups and } \\
\text { guides each group to make the transition effectively and efficiently }\end{array}$ \\
\hline $\begin{array}{c}\text { Phase 4 Guiding group work } \\
\text { and study }\end{array}$ & The teacher guides the study groups as they do their assignments \\
\hline $\begin{array}{c}\text { Phase 5 Evaluation } \\
\text { Phase 6 Giving } \\
\text { award }\end{array}$ & $\begin{array}{l}\text { The teacher evaluates the learning outcomes about the material that } \\
\text { has been studied or each group presents their work }\end{array}$ \\
\hline $\begin{array}{l}\text { Teachers look for ways to appreciate both individual and group } \\
\text { learning processes and outcomes }\end{array}$ \\
\hline
\end{tabular}

Learning outcomes are an important factor in education. In general, learning outcomes are always seen as the embodiment of the value obtained by students through the learning process. Ananda et al., (2015) stated that learning outcomes are the results achieved by students in the form of numbers after being given a test of learning outcomes at the end of a meeting, mid-semester, or end of the semester. From the understanding of the learning outcomes, it can be concluded that the learning outcomes referred to in this study are changes in behavior from not being able or unable to be able after the learning process through STAD type cooperative learning (Siahaan, Haloho, et al., 2021). Civics learning outcomes in this study are the learning outcomes achieved by students after being given an assignment at the end of the lesson. Rahman, (2018) suggests that learning outcomes are the overall learning achievement of students, which is an indicator of competence and the degree of change in the behavior in question.

\section{RESEARCH METHODS}

The action research design used is classroom action research (CAR) which aims to improve the quality of learning. As stated by Arikunto Suharsimi, (2016) stated that classroom action research is an activity of observing an object by using certain rules to obtain useful information and aims to improve or improve the quality of learning practices.

This study was conducted at SMA Negeri 3 Pematangsiantar. The subjects of this study were students of class X-4 SMA Negeri 3 Pematangsiantar, which consisted of 30 heterogeneous people. This research was conducted in two cycles, where each cycle consisted of 3 meetings, the cycle of classroom action research (CAR). Arikunto Suharsimi, ( 2016) the phases that will be passed in classroom action research can be described as below. 


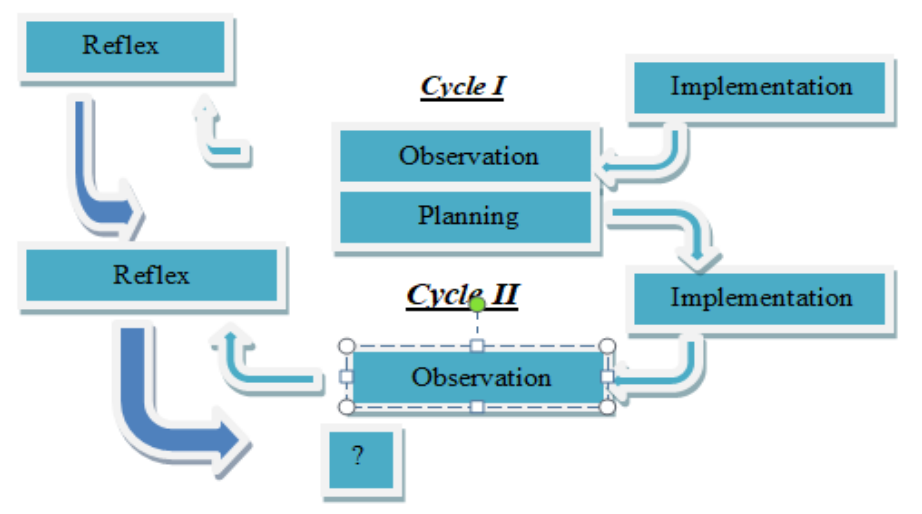

\section{Planning}

Figure 1. Picture of Classroom Action Research in CAR

This research consists of compiling learning instruments, which include setting learning indicators, observation sheets, indicators of student success, syllabus preparation, to making research tools.

\section{Action}

The implementation of the action is the implementation of the plan made. Implementation of learning programs, collecting data from observations and test results.

\section{Observation}

Observation serves to see the effects of actions in the classroom. The results of observations are the basis for reflection so that observations can tell the real situation. The things that need to be noted by the author are the process of the action, the effects of the action, the environment, and the obstacles that arise.

\section{Reflection}

After the improvement of learning is carried out, the teacher and observer conduct discussions and analyze the results of the learning process carried out, so that the success and weaknesses of the learning that have been implemented are known.

The data used in this study are a teacher and student activity data and student learning outcomes data. While the instruments used in this study were: (1) observation sheets for teacher and student activities; and (2) objective questions with five alternative answers with a total of 20 questions. The data collection techniques used in this study were (1) observation techniques and (2) test techniques for student Civics learning outcomes (Rizki Ananda \& Fadhilaturrahmi, n.d.).

\section{FINDINGS AND DISCUSSION}

The data collected in this study is data about the activities of teachers and students in the learning process and the achievement of KKM student learning outcomes of Civics.

\section{Teacher Activity Data}

There is also data on teacher activities can be seen in the table below.

Tabel 2. The results of the teacher's activity cycle I and II

\begin{tabular}{c|c|c|c|c|c}
\hline Number & Teacher Activity & Cycle I & Criteria & \multicolumn{2}{|c}{ Cycle II } \\
& & P1 & P2 & P1 & P2 \\
1. & Total score & 12 & 17 & 21 & 24 \\
2. & Score & $52,16 \%$ & $77,16 \%$ & $93,83 \%$ & $100 \%$ \\
3. & Category & deficient & good & good & Very \\
& & & & & good \\
\hline
\end{tabular}


The acquisition of teacher activity at the first meeting of the first cycle was in the poor category with an average of $52.16 \%$. The second meeting increased with a percentage of $77.16 \%$ in the good category. Cycle II, the first meeting in the very good category with an average of $93.83 \%$. The second meeting increased in the very category, with an average of $100 \%$. Thus, the teacher's activity at the first and second meetings in the first cycle indicates that the teacher's activity is still relatively low, while in the second cycle the teacher's activity is good.

The increase in teacher activity in the learning process means that the teacher has positioned himself as an educator in the learning process which functions as a facilitator and motivator to make learning more meaningful.

\section{Student Activity Data}

The data on student activity in cycles I and II can be seen from the table below:

Tabel 3. Results of student activities in Cycles I and II

\begin{tabular}{cccccc}
\hline Number & Teacher Activity & Cycle I & Criteria & \multicolumn{2}{c}{ Cycle II } \\
\hline & & P1 & P2 & P1 & P2 \\
\hline 1. & Total score & 11 & 17 & 20 & 24 \\
\hline 2. & Score & $52,16 \%$ & $70,83 \%$ & $89,66 \%$ & $100 \%$ \\
\hline 3. & Category & deficient & good & good & $\begin{array}{c}\text { Very } \\
\text { good }\end{array}$ \\
\hline
\end{tabular}

Analysis of data about student activities that have been collected is done by observing data based on observation sheets. Completeness of student activities in the first cycle of the first meeting was in the sufficient category with a percentage of $52.16 \%$. At the second meeting, it increased to $70.83 \%$ with sufficient category. Furthermore, in the second cycle, the first meeting increased to $89.66 \%$ in the good category and the second meeting increased to $100 \%$ in the very good category.

The low activity of students in the first cycle was because students were not familiar with the student teams achievement division (STAD) cooperative learning model, and there was still a lack of teacher guidance for students in the implementation of learning. However, in the second cycle, it began to increase, this showed that students were able to place themselves as learning subjects who had to move to achieve learning goals.

Teachers are also required to be rich in teaching methodologies and skilled in applying learning models, not monotonous, and varied in learning so that the learning atmosphere is more pleasant. Good learning should be able to help students develop themselves optimally and be able to achieve learning goals.

\section{Civics Learning Outcomes Data}

Learning outcomes can be seen from cycle I and cycle II. The learning outcomes of the first cycle are calculated based on the difference between the scores of learning outcomes before the action (basic score) and the scores of learning outcomes on the daily test I. While the student learning outcomes in the second cycle are obtained from the difference in the scores of the daily test I and the score of the daily test II

Table 4. Results of completeness analysis based on initial data, repetition of cycles I and II

\begin{tabular}{ccccccc}
\hline Total Value & Average value & \multicolumn{2}{c}{$\begin{array}{c}\text { Individual } \\
\text { Completeness }\end{array}$} & \multicolumn{2}{c}{$\begin{array}{c}\text { Classical } \\
\text { Completeness }\end{array}$} \\
\hline & & & & & & \\
\hline DA & 876 & 48,61 & 13 & 17 & $33 \%$ & Deficient \\
\hline UH I & 1180 & 66,56 & 19 & 11 & $72,50 \%$ & Good \\
\hline UH II & 1290 & 71,67 & 25 & 5 & $87,50 \%$ & $\begin{array}{c}\text { Very } \\
\text { good }\end{array}$ \\
\hline
\end{tabular}


From the table above, it can be seen that the students' test results increased. In the first cycle test, the average value of the test was 65.56 Students who completed as many as 29 people $(72.50 \%)$. While in the second cycle the average value increased to 71.67 with the completeness of 25 people $(87.50 \%)$. So the increase in student learning outcomes increases both individually and classically. From the data above, it can be concluded that the use of cooperative learning model type student teams achievement division (STAD) can improve Civics learning outcomes for students in class X-4 State Senior High School 3 Pematangsiantar.

Based on the analysis of the research results obtained primary data in the form of daily tests, conclusions about the activities of teachers and students, as well as the achievement of KKM (Minimum Completeness Criteria) and the success of the action. For teacher and student activities, it can be concluded that they are following the learning plan. Analysis of data on the development of student scores showed an increase in learning outcomes after the action. Analysis of the data on the achievement of the KKM obtained the fact that there was an increase in the number of students who achieved the KKM from before the action compared to cycle I. Before the auction was held, the average initial data for student completeness was $33.33 \%$, cycle I was $72.50 \%$, and cycle II was $87.50 \%$. Thus, the class can be said to be complete and achieve the KKM target that has been set.

The weaknesses in research by applying the STAD type of cooperative learning model are the limited time available so that researchers find it difficult to control each group optimally and when the group presents the group's results some groups have not been able to respond well.

From the analysis of data about learning outcomes through daily tests, there was an increase in cycle I and cycle II. This is caused by several factors, including (a) In groups students have the opportunity to ask questions with their groups so that in groups students are motivated to learn; and (b) Through the STAD type cooperative learning model, students' curiosity about the subject matter is very high, so that the learning objectives can be achieved properly. The improvement of student learning outcomes based on completeness has been fulfilled if each individual has reached $65 \%$ of the number of questions given or with a value of 65 , the student is said to be complete from the material being taught which is mastered by each individual. However, for students who have not finished, they are given a remedial program so that it can reach $65 \%$. In this study, 5 people did not complete.

Students' learning mastery has increased starting from the basic score, daily test I, and daily test II. On the basic score of students who completed only 6 students. In UH I cycle I, 27 students completed. While in UH II cycle II students completed 35 students. Each stage in the application of the STAD type cooperative learning model has increased. Furthermore, the comparison of teacher activities from the first meeting to the last meeting has increased. At the first meeting, the teacher's activity was an average of $54.16 \%$, the second meeting of the first cycle with an average of $79.16 \%$. The first meeting of the second cycle with an average of $95.83 \%$ and the second meeting of the second cycle with an average of $100 \%$. During the research process, researchers used the STAD type of cooperative learning model at State Senior High School 3 Pematangsiantar, which continued to increase. After the development of teacher activities, the development of student activities from the first meeting to the last meeting increased. The first meeting of the first cycle of student activity was only $54.16 \%$, the second meeting of the first cycle was $70.83 \%$. The first meeting of the second cycle was $91.66 \%$ while at the last meeting of the second cycle it was $100 \%$. During this research, researchers used the STAD type of cooperative learning model at the State Senior High School 3 Pematangsiantar, which continued to increase.

Thus, it can be concluded that the research hypothesis reads that if the student teams achievement division (STAD) type cooperative learning model is applied, it can improve the Civics learning outcomes for class X-4 SMA Negeri 3 Pematangsiantar is acceptable. 
3048 Implementation of the STAD Type Cooperative Learning Model to Improve Students' Motivation and Civics Learning Outcomes - Sepriandison Saragih

DOI: https://doi.org/10.31004/basicedu.v5i5.1238

\section{CONCLUSION}

Based on the results of the research and discussion, it can be concluded that the application of the Student Teams Achievement Division (STAD) Cooperative Learning Model can improve student learning outcomes, student activities, and teaching activities in the learning process. The results of observations of teacher activities in cycle I, the first meeting was in the poor category with a percentage of $52.16 \%$. At the second meeting, it increased with a good category the percentage of $77.16 \%$. In the first cycle of the second meeting the category was very good with a percentage of $93.83 \%$, and at the second meeting the category was also very good with a percentage of $100 \%$. The results of the observation of student activity in the first cycle, the first meeting was in the poor category with a percentage of $52.16 \%$, at the second meeting the category was sufficient with a percentage of $70.83 \%$. In cycle II, the first meeting was in the good category with a percentage of $89.16 \%$, and the second meeting was in the very good category with a percentage of $100 \%$. Student learning outcomes on the basic score of the average value of 48.61 increased by 16.95 points to 65.56 in the first cycle. In the second cycle the average score was 71.67, an increased from the first cycle of 6.11 points. Classical completeness on a base score of 33\% (13 students). In the first cycle test, the completeness increased to $72.5 \%$ (19 students). In the second cycle, classical completeness increased to $87.5 \%$ (25 students).

\section{ACKNOWLEDGEMENTS}

Thanks to HKBP Nommensen Pematangsiantar University and LPPM HKBP Nommensen University who have supported this research.

\section{REFRENCE}

Ananda, Rizki, \& Fadhilaturrahmi, F. (N.D.). Analisis Kemampuan Guru Sekolah Dasar Dalam Implementasi Pembelajaran Tematik Di SD. Jurnal Basicedu, 2(2), 11-21.

Ananda, Rusydi, Rafida, T., \& Syahrum, S. (2015). Penelitian Tindakan Kelas.

Arikunto Suharsimi, D. (2016). Penelitian Tindakan Kelas. Jakarta: Bumi Aksara.

Muchtarom, M. (2017). Pendidikan Karakter Bagi Warga Negara Sebagai Upaya Mengembangkan Good Citizen.

Nanggala, A. (2020). Citizenship Education As A Democracy Learning For Students In Higher Education. IJECA (International J. Educ. Curric. Appl., Vol. 3, No. 1, Pp. 69-80.

Nasozaro, H. O. (2019). Pembangunan Karakter Bangsa Melalui Pendidikan Kewarganegaraan. Warta Dharmawangsa, 13(4).

Octavia, S. A. (2020). Model-Model Pembelajaran. Deepublish.

Pangalila, T. (2017). Peningkatan Civic Disposition Siswa Melalui Pembelajaran Pendidikan Kewarganegaraan (Pkn).

Pratama, F. A., Al-Ghozali, M. I., \& Sarie, D. M. (2019). VCT (Role Playing) Model To Increase Awareness Of Democratic Value In Citizenship Learning. Action Research Journal Indonesia (ARJI), 1(1), 41-51.

Priansa, D. J. (2017). Pengembangan Strategi Dan Model Pembelajaran: Inovatif, Kreatif, Dan Prestatif Dalam Memahami Peserta Didik.

Rahman, T. (2018). Aplikasi Model-Model Pembelajaran Dalam Penelitian Tindakan Kelas. CV. Pilar Nusantara.

Siahaan, K. W. A., Haloho, U. N., Guk-Guk, M. P. A. R., \& Panjaitan, F. R. (2021). Implementation Of 
3049 Implementation of the STAD Type Cooperative Learning Model to Improve Students' Motivation and Civics Learning Outcomes - Sepriandison Saragih

DOI: https://doi.org/10.31004/basicedu.v5i5.1238

Discovery Learning Methods To Improve Science Skills In Kindergarten B Children. Jurnal Pendidikan Edutama, 8(1), 33-40.

Siahaan, K. W. A., Lumbangaol, S. T. P., Marbun, J., Nainggolan, A. D., Ritonga, J. M., \& Barus, D. P. (2021). Pengaruh Model Pembelajaran Inkuiri Terbimbing Dengan Multi Representasi Terhadap Keterampilan Proses Sains Dan Penguasaan Konsep IPA. Jurnal Basicedu, 5(1), 195-205.

Silvia, M. R., Suntoro, I., \& Nurmalisa, Y. (2012). Learning Effect Of Citizenship Education Students In Application Of Character Value. Jurnal Kultur Demokrasi, 1(4).

Simanjuntak, L., Sriadhi, S., \& Saragi, D. (2020). The Effect Of Project Based Learning Models And Learning Motivation On Civics Learning Results In 4th Grade Primary School 106163 Percut Sei Tuan. Budapest International Research And Critics In Linguistics And Education (Birle) Journal, 3(3), 15091520.

Zuriah, N. (2020). Model Pengembangan Pendidikan Kewarganegaraan Multikultural Berbasis Kearifan Lokal Dalam Fenomena Sosial Pasca Reformasi Di Perguruan Tinggi. JIP Jurnal Ilmu Pendidikan, 1(1), $11-25$. 